\title{
Properties of $\mathrm{CO}_{2}$ adsorption for petrographically diverse ortho-lignites and some higher rank coals
}

\author{
Damjan HANN ${ }^{1}$, Jože $\check{Z} A R N^{2}$ and Miloš MARKICั
}

\begin{abstract}
Authors' affiliations and addresses:
${ }^{1}$ University of Ljubljana, Faculty of Natural

Sciences and Engineering, Department of

Geotechnology, Mining and Environment,

Aškerčeva 12, Ljubljana, Slovenia

e-mail: damjan.hann@ntf.uni-lj.si

${ }^{2}$ University of Ljubljana, Faculty of Natural Sciences and Engineering, Department of Geotechnology, Mining and Environment, Aškerčeva 12, Ljubljana, Slovenia e-mail: joze.zarn@ntf.uni-lj.si
\end{abstract}

${ }^{3}$ Geological Survey of Slovenia, Dimičeva ulica 14, Ljubljana, Slovenia e-mail: Milos.Markic@GEO-ZS.SI

\section{*Correspondence:}

Damjan Hann, University of Ljubljana, Faculty of Natural Sciences and Engineering, Department of Geotechnology, Mining and Environment, Aškerčeva 12, Ljubljana, Slovenia

tel.: +38641892698

e-mail: damjan.hann@ntf.uni-lj.si

\section{Funding information:}

Slovenian Research Agency

L2-4066

\section{Acknowledgement:}

This study was conducted in the frame of the L2-4066 project entitled "Petrology of Brown Coals as Produced and/or Used in Slovenia, Gases in Them and Their Gas-sorption Characteristics" financed by the Slovenian Research Agency.

How to cite this article:

Hann, D., Žarn, J. and Markič, M. (2020). Properties of $\mathrm{CO}_{2}$ adsorption for

petrographically diverse ortho-lignites and some higher rank coals. Acta Montanistica Slovaca, Volume 25 (3), 324-336

\section{DOI:}

https://doi.org/10.46544/AMS.v25i3.6

\begin{abstract}
A great deal of research has been done worldwide on the assessment of realistic $\mathrm{CO}_{2}$ adsorption capacities of different coals, which is important for the understanding and predicting of processes associated with the geological storage of carbon dioxide $\left(\mathrm{CO}_{2}\right)$. The focus of this article is on measuring the $\mathrm{CO}_{2}$ amounts adsorbed by coals regarding their petrographic type and coalification rank. Most of the samples were taken from the Velenje lignite seam (ortho-lignite, Slovenia). Samples of meta-lignites and bituminous coals from Hrastnik (metalignite, Slovenia), Raša (bituminous coal, Croatia) and the Sokolov Basin (meta-lignite, Czech Republic) have been analysed as comparing coals. Adsorption measurements were undertaken using the gravimetric method at the temperature of $21{ }^{\circ} \mathrm{C}$ and the $\mathrm{CO}_{2}$ pressure of $3 \mathrm{MPa}$. The measurements show that different ortho-lignite lithotypes (dried, ground, and under $200 \mu \mathrm{m}$ sieved material, compressed under uniaxial compression of $9 \mathrm{MPa}$ and filled with $\mathrm{CO}_{2}$ ) adsorbed on average $29 \mathrm{~m}^{3}$ of $\mathrm{CO}_{2}$ per tonne of lignite, varying from 22 to $39 \mathrm{~m}^{3}$ of $\mathrm{CO}_{2}$ per tonne of lignite. However, higher rank coals adsorbed slightly more $\mathrm{CO}_{2}$, that is, between 31 and $42 \mathrm{~m}^{3}$ of $\mathrm{CO}_{2}$ per tonne of coal.
\end{abstract}

\section{Keywords}

carbon dioxide, lignite lithotype, Velenje lignite, Slovenia 


\section{Introduction}

Thermal power plants running on different coals are still very important producers of electricity in the world (Nemitallah et al., 2019). They are, however, also one of the greatest contributors of $\mathrm{CO}_{2}$ emissions into the atmosphere. Even at plants where new units were recently installed in accordance with BAT (best available technologies), options for minimisation of greenhouse gas emissions are still limited. Consequently, $\mathrm{CO}_{2}$ sequestration into deep coal seams is a promising option regarding the high prices of $\mathrm{CO}_{2}$ allowances and public pressure due to environmental pollution (De Silva and Ranjith, 2014; Nagy, 2006; Tajnik et al., 2013). This is a particularly convenient choice for those thermal power plants, where coal deposits are close to the power plant and where part of estimated coal resources will not be excavated due to densely populated areas above coal layers or due to some other reasons. Such a case is also the Velenje Coal Mine and the nearby Šoštanj Thermal Power Plant.

The Velenje Coal Mine, from which most of the samples for this study have been collected, is an underground mine exploiting an intermountain mega-lenticular seam. Lignite is mined from the depth of 200 to $500 \mathrm{~m}$, with an annual production about $3.5 \mathrm{Mt}$. The lignite seam is on average $60 \mathrm{~m}$ thick, $8.3 \mathrm{~km}$ long and up to $2.5 \mathrm{~km}$ wide (Brezigar, 1987; Brezigar et al., 1987; Vrabec, 1999). The Šoštanj Thermal Power Plant (ca. $1000 \mathrm{MW}$ ) produces about 35\% of electricity consumed in Slovenia. Lignite burning in this power plant is planned for the coming decades. $\mathrm{CO}_{2}$ emissions diminished in the last 30 years due to technological improvements and are expected to decrease in the coming years as well. Nevertheless, they will still be an environmental problem.

Worldwide, possibilities to capture and store $\mathrm{CO}_{2}$ into deep coal seams (besides deep saline aquifers and depleted hydrocarbon fields) have been studied (Hartai, 2014; Leung et al., 2014), and also applied in the last 25 years. Coals are suitable for carbon dioxide storage because they are highly porous materials that enable the sorption of $\mathrm{CO}_{2}$ into their porous structure.

Most world studies of $\mathrm{CO}_{2}$ sorption into coals are dealing with sub-bituminous and bituminous coals (Pini et al., 2010; Saghafi et al., 2007). Our study primarily intends to contribute to the understanding of $\mathrm{CO}_{2}$ adsorption into ortho-lignite, to examine its capacity for "storing" $\mathrm{CO}_{2}$ after injection in its different lithotypes. Moreover, this study contributes new results to the previous investigations of $\mathrm{CO}_{2}$ adsorption of coals in particular of lignites carried out by somewhat different approaches (Likar et al., 2008; Zapušek and Hočevar, 1998; Žula et al., 2011).

Apart from methane $\left(\mathrm{CH}_{4}\right), \mathrm{CO}_{2}$ is in many cases the main naturally occurring gas in coals. From the studies dealing with gasses in lignite (Kanduč and Pezdič, 2005; Kanduč et al., 2003; Lazar et al., 2014; Si et al., 2015), it is well known that $\mathrm{CO}_{2}$ and $\mathrm{CH}_{4}$ are of different origins and that they mix in very different ratios in different zones of the seam. They are dangerous because they can cause gas exhalations and/or gas and coal outbursts into mine workings. Between these two gasses, $\mathrm{CO}_{2}$ seems to be even more dangerous than $\mathrm{CH}_{4}$ because it is less mobile, more tightly adsorbed, and if exhalated it accumulates at the bottom of the mine workings.

The Velenje lignite is a typical ortho-lignite, according to the International Classification of in-Seam Coals (ECE-UN, 1998). Therefore, we presume that our study will also contribute to the understanding of $\mathrm{CO}_{2}$ adsorption properties of lignites in general.

\section{Material and Methods}

\section{Adsorbed gas volume determination}

Coal is defined as a sedimentary rock composed prevailingly of lithified organic matter. It contains less than $50 \mathrm{wt} \%$ of ash on a dry basis (ECE-UN, 1998). It is coalified to different degrees, that is, coal rank: from peat, through lignite (ortho- and meta-), sub-bituminous coal, bituminous coal to anthracite. In general, coal is a porous material characterised by a mixture of micro-, meso- and macro-pores. Micro-pore diameters are less than 2 nanometers $(\mathrm{nm})$, meso-pore diameters are 2-50 nm, while macro-pore refers to pores of diameters larger than $50 \mathrm{~nm}$ (Flores, 2014; Gan et al., 1972; Senel et al., 2001). Gas molecules adsorbed to the surfaces of pores are much smaller. The size of the main gas molecules is as follows: $\mathrm{CO}_{2}-0.33 \mathrm{~nm}, \mathrm{CH}_{4}-0.38 \mathrm{~nm}$ and $\mathrm{N}_{2}-0.36$ nm (Flores et al., 2008; Kurniawan et al., 2006).

The highest possible stored quantity of gas in coal is an aggregate of the adsorbed gas on micro-pore surfaces and the gas trapped in macro-pore systems. However, as reported by Saghafi et al. (2007), the quantity of the adsorbed gas greatly exceeds the quantity of gas trapped in pores. Most $\mathrm{CO}_{2}$ in coals is therefore stored in the adsorbed state in micro-pores. The reverse situation is rare and only possible in the case of very high gas pressure and water-free macro-pores.

The volume of gas that can be adsorbed into coal is a function of the energy that a free gas possesses. Energy obviously depends on temperature and pressure. When these parameters are constant over time, the 
adsorbed and free phase achieve kinetic equilibrium. Consequently, the degree of adsorption and desorption is equal.

In this research, the adsorption capacities were obtained with measurements of adsorption isotherms using the gravimetric method as described and physically ascertained by Saghafi et al. (2007). This method is based on direct measurement of the increase in weight of a geological material as it is saturated with gas at a defined gas pressure. Figure 1 presents the assembled measuring system, which was used in our experiment. The $\mathrm{CO}_{2}$ source is connected to both measuring and reference cells that are filled with gas at the same time. Scales are connected to a computer, through which data on the mass rising in both cells versus time is collected. Gathered data from such adsorption graphs is the basis for further calculation. A typical adsorption isotherm for gravimetric measuring of the adsorbed gas in a geological material is shown in Figure 2.

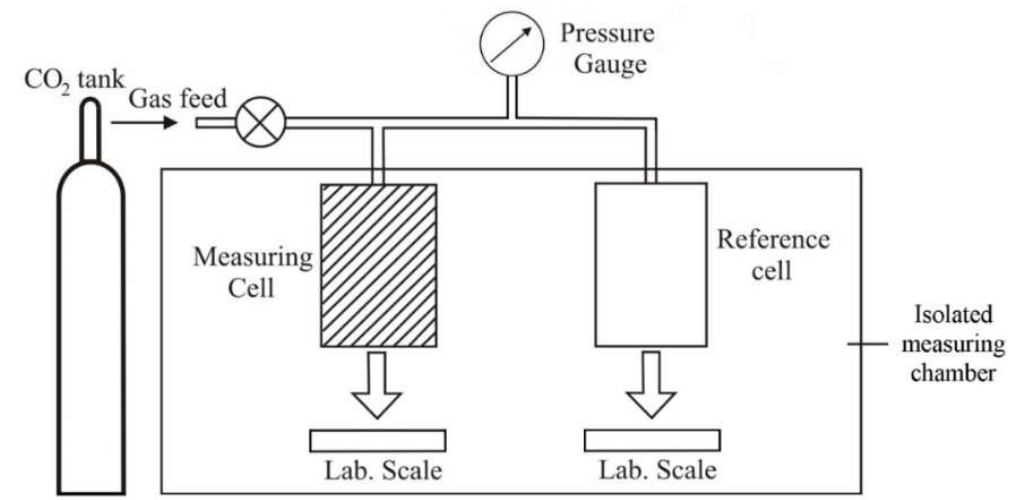

Fig. 1. System for gravimetric measuring of the $\mathrm{CO}_{2}$ amount in geological materials (Saghafi et al., 2007)

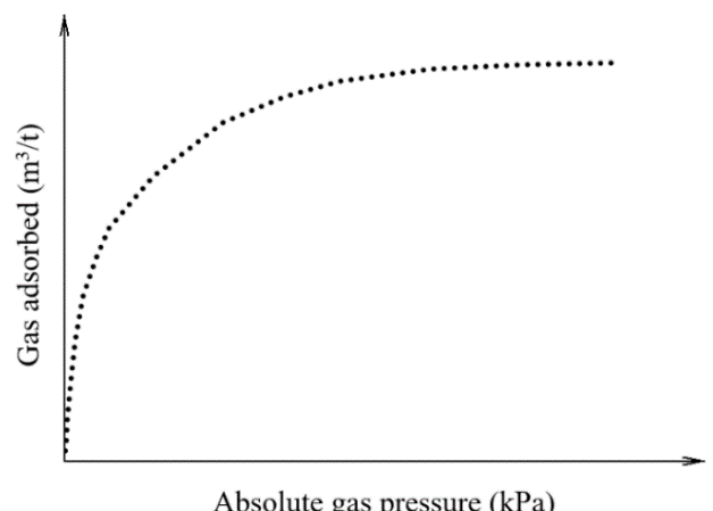

Fig. 2. Typical adsorption isotherm for gravimetric measuring of the adsorbed gas in geological material (Saghafi et al., 2007)

Mass increase of an empty reference cell and a cell filled with the sample is measured when both cells are exposed to the same gas pressure. The aim of the reference cell is to get data to calculate the density of gas at measurement pressure and temperature (Saghafi et al., 2007):

$$
d_{\mathrm{g}}=\frac{w_{\text {ref }}}{V_{\text {ref }}},
$$

where:

$w_{\text {ref }}$ - measured mass of gas in the reference cell

$V_{\text {ref }}$ - the volume of the reference cell.

The excess mass can be calculated with the expression:

$$
w_{\mathrm{G}}=w-V_{\text {void }} \cdot d_{\mathrm{g}}
$$

where:

$w$ - a mass of gas in the measuring cell, 
$V_{\text {void }}$ - uncorrected volume of the void (the difference between the volume of the empty canister and the volume of coal).

To get actual adsorbed gas mass, the void volume in the measuring cell must be corrected for the volume of adsorbed gas, which partly occupies the initial void. The net void volume is, therefore:

$$
\left(V_{\text {void }}\right)_{\mathrm{t}}=V_{\text {void }}-\frac{w_{\text {ads }}}{d_{\text {ads }}}
$$

where:

$d_{\text {ads }}$ - adsorbed gas density

$w_{\text {ads }}$ - adsorbed gas mass.

The adsorbed gas mass:

$$
w_{\mathrm{ads}}=w-\left(V_{\mathrm{void}}\right)_{\mathrm{t}} \cdot d_{\mathrm{g}}
$$

Using an expression for net void volume (eq. 3) in the expression for adsorbed gas mass (eq. 4), the adsorbed gas mass is:

$$
w_{\mathrm{ads}}=\frac{w_{\mathrm{G}}}{1-\frac{d_{\mathrm{g}}}{d_{\mathrm{ads}}}}
$$

The adsorbed volume of gas at standard conditions is:

$$
V_{\mathrm{ads}}=\frac{w_{\mathrm{ads}}}{d_{\mathrm{g}}^{\mathrm{st}}},
$$

where:

$V_{a d s}$ - adsorbed gas volume at standard conditions

$d_{g}{ }^{s t}-$ gas density at standard conditions (gas pressure $101.325 \mathrm{kPa}$, temperature $20{ }^{\circ} \mathrm{C}$ ).

The volume of adsorbed $\mathrm{CO}_{2}$ per tonne of material is:

$$
c_{\mathrm{ads}}=\frac{V_{\mathrm{ads}}}{w_{\mathrm{c}}},
$$

where:

$\mathrm{w}_{\mathrm{c}}-$ the mass of coal sample.

In this research, the value $0.915 \mathrm{~g} / \mathrm{cm}^{3}$ as adsorbed $\mathrm{CO}_{2}$ density $\left(d_{\text {ads }}\right)$ was used after Walker and Mahajan (1978), although other proposed values can also be found in the literature (Angus et al., 1976; Fitzgerald et al., 2005; Hall et al., 1994; Humayun and Tomasko, 2000; Span and Wagner, 1996; Sudibandriyo et al., 2010).

The major problem, associated with the reliability of measuring adsorption isotherms with a system assembled, is due to the high pressure connected to cell sealing. To verify this, the relative error was calculated based on the relation between the measured maximum and final mass of the gas in the reference cell (Fig. 3, Tab. 2). Furthermore, the measurement uncertainty of the system was verified by measuring and calculating the value of $\mathrm{CO}_{2}$ adsorbed on the same sample and was $\pm 3.2 \%$. 


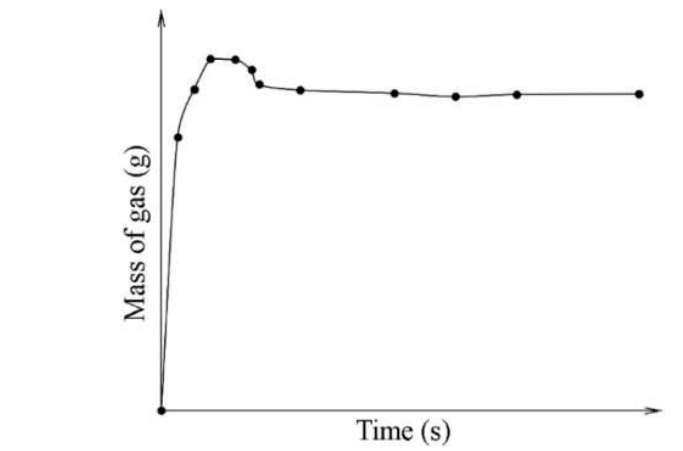

Fig. 3. The typical measurement of gas mass in the reference cell

\section{Samples}

In order to compare the adsorption capacities, coal samples of various lithotypes and ranks were gathered from different locations. Set of samples was composed of the following coals:

- ortho-lignite (Velenje, Slovenia, Velenje Basin, Pliocene, samples 1V to 8V) (Markič et al., 2001; Markič and Sachsenhofer, 2010);

- meta-lignite - durain (Hrastnik, Slovenia, Sava Folds, Oligocene, sample 9H) (Hamrla, 1959; Bruch 1998);

- $\quad$ bituminous coal - vitrain (Raša, Croatia, Adria Foreland, Paleogene, samples 10R to 12R) (Medunić et al. 2020);

- meta-lignite - durain (Sokolov, Czech Republic, Sokolov Basin, Miocene, sample 13S) (Rojik et al., 2014).

The vast majority of samples are from the Velenje lignite seam. They were taken from three underground borehole cores in the active mining area. Originally, the set of samples from Velenje included 20 samples, but it was later reduced to 8 samples with combining two or three samples with very similar lithotype composition. The combining of samples was necessary in order to obtain sufficient sample quantity for the adsorption testing. Other coals were studied mostly as comparing ones. They were taken from the coal seams in the underground mines of Hrastnik and Raša, and from a coal seam in the opencast mining area of the Sokolov Basin. It was expected that the ortho-lignite samples, which represent coals of the lowest coalification rank, will show somewhat different $\mathrm{CO}_{2}$ adsorption characteristics, most probably lower than the higher rank coals. Noticeable differences were also expected within the ortho-lignite samples due to considerable lithotype heterogeneity (Markič et al., 2001; Markič and Sachsenhofer, 2010). The following lithotype components were distinguished (Fig. 4): xylite (X; xylite-rich coal; ICCP, 1993; Taylor et al., 1998), detro-xylite (dX; Markič and Sachsenhofer, 2010), xylo-detrite ( $x D$; Markič and Sachsenhofer, 2010), and fine detrite ( $D$; matrix coal; ICCP, 1993; Taylor et al., 1998). Xylite lithotype is a fossil-wood appearing in pieces larger than $64 \mathrm{~mm}$ (i.e., average borehole diameter). On the contrary, detrite or matrix lithotype is composed of fine plant detritus that passed early coalification during the peat-to-lignite transformation process. This is called biochemical gelification, which affected plant detritus more easily and rapidly than xylites (Diessel, 1992; Stach et al., 1982; Taylor et al., 1998). Detrite is homogeneously dark brown (weakly gelified; ICCP, 1993; Taylor et al., 1998) to black (gelified; ICCP, 1993; Taylor et al., 1998). Detro-xylite and xylo-detrite contain xylitic pieces within fine-detrital matrix. In the case of detro-xylite, the woody pieces are larger than $32 \mathrm{~mm}$, whereas in xylo-detrite lithotype they are smaller than $32 \mathrm{~mm}$ (Fig. 4).

The lithotype petrographic composition of the ortho-lignite samples, expressed in volume percentages, is given below in Table 1. The lithotype composition was determined macroscopically in terms of lithotype components as observed on samples of borehole cores (Markič and Sachsenhofer, 2010). The samples were covered with a transparent PVC foil with a $3 \times 3 \mathrm{~mm}$ grid. For each core sample with a diameter of $64 \mathrm{~mm}$ and a length of $150 \mathrm{~mm}$, the total area of xylite, detro-xylite, xylo-detrite and fine detrite was determined by summing up all individual $3 \times 3 \mathrm{~mm}$ squares representing a specific lithotype component. The composition determined on the surface of the core samples was considered to correlate well with the volume content of the individual lithotype components in the samples. However, in order to ensure that the interior of the core samples did not deviate from the findings at the outer surface, lithotype composition was visually assessed even after the core samples had been crushed to a particle size of approx. $10 \mathrm{~mm}$. In all considered cases, the interior followed the findings obtained at the surface, so Table 1 shows the volume contents. 
Tab. 1. Macroscopically estimated lithotype composition of ortho-lignites

\begin{tabular}{|c|c|c|c|c|}
\hline \multirow{2}{*}{ 茎 } & \multicolumn{4}{|c|}{ Lithotype composition } \\
\cline { 2 - 5 } & $X$ & $d X$ & $x D$ & $D$ \\
\cline { 2 - 5 } & \multicolumn{4}{|c|}{ [vol. \%] } \\
\hline $1 \mathrm{~V}$ & 93 & 0 & 0 & 7 \\
\hline $2 \mathrm{~V}$ & 85 & 0 & 0 & 15 \\
\hline $3 \mathrm{~V}$ & 25 & 10 & 20 & 45 \\
\hline $4 \mathrm{~V}$ & 10 & 5 & 10 & 75 \\
\hline $5 \mathrm{~V}$ & 0 & 1 & 6 & 93 \\
\hline $6 \mathrm{~V}$ & 0 & 0 & 2 & 98 \\
\hline $7 \mathrm{~V}$ & 0 & 5 & 12 & 83 \\
\hline $8 \mathrm{~V}$ & 65 & 15 & 9 & 11 \\
\hline
\end{tabular}

\section{$64 \mathrm{~mm}$}
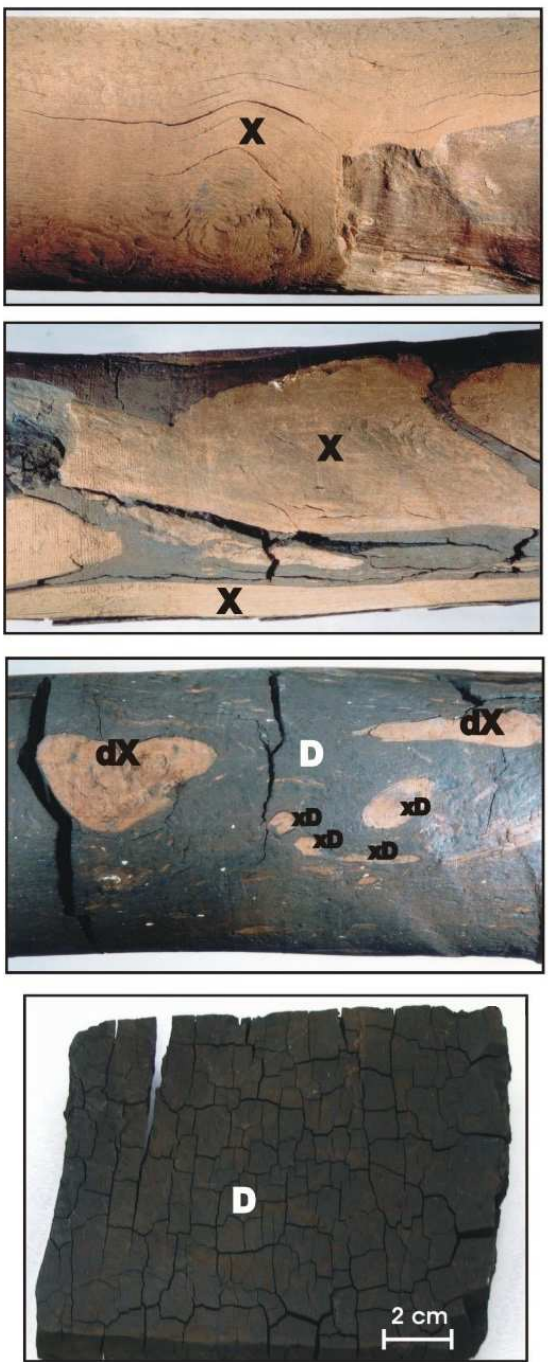

xylite $(\mathbf{X})$, wholy extending over dimensions of core diameter

xylite fragments $(\mathbf{X})$ of different shapes, all longer than $64 \mathrm{~mm}$

the biggest two xylites are larger than $32 \mathrm{~mm}$, pieces are detro-xylite (dX), pieces between 1 and $32 \mathrm{~mm}$ in size are termed xylo-detrite (xD), dark homogenous graundmass (matrix) and the smallest $(<1 \mathrm{~mm})$ xylite lenses are termed fine detrite (D)

homogenous, typically fractured fine detrital lignite, as a whole fine detrite (D)

Fig. 4. Macropetrographic lithotype heterogeneity of the Velenje ortho-lignite (Markič et al., 2001; Markič and Sachsenhofer, 2010)

For meta-lignites and bituminous coals, a conventional lithotype nomenclature was applied differentiating among the following lithotypes: vitrain, clarain, durain and fusain (Taylor et al., 1998). However, only durain (meta-lignite) and vitrain (bituminous coal) occur in the samples studied.

Prior to adsorption testing, the samples were dried for approximately two hours in an oven at $105^{\circ} \mathrm{C}$ to the constant weight. Then they were crushed with a jaw crusher to about $1 \mathrm{~cm}$. This was followed by milling in a disc mill and sieving to get an appropriate fraction for the analyses of adsorption, that is, below $200 \mu \mathrm{m}$. 
Proximate coal analysis was carried out in order to get the information on calorific value, moisture content and ash yield (high-temperature ashing) of the investigated samples. In this study, only data on the ash yield recalculated to the dry basis are considered.

In order to improve the understanding of lithotype varieties, the lignite samples were also investigated microscopically in terms of the semi-quantitative maceral analysis as described by Taylor et al. (1998). Dry samples were crushed to 1-2 mm particle size, mixed with resin, vacuumed and prepared as polished blocks $(3 \times 3 \mathrm{~cm})$ for the observation in normal reflected light under magnifications of up to $\times 200$. Macerals are basic microscopic ingredients of coals. In our study, maceral composition was defined according to ISO 7404-3 (2009) with the determination of 500 points in coal per polished block. The total maceral semi-quantitative composition was then calculated as the sum of the partial compositions. Macerals were determined using the classification of huminite macerals by Sýkorová et al. (2005). The following macerals were distinguished: textinite, ulminite, attrinite and densinite. The first two macerals are larger tissues with well-preserved cellular structure (textinite) to uniformly gelified tissues of homogeneous appearance (ulminite). Attrinite and densinite originate from fine plant detritus $(<50 \times 50 \mu \mathrm{m})$. Attrinite looks like detritus with clearly distinguishable edges of particles, whereas densinite is homogenous due to the high degree of gelification. Distinguishing ulminite and densinite can be critical; however, the physical properties of these two highly gelified macerals are quite similar. The content of mineral matter was also determined.

\section{Results and discussion}

In the present study, gas adsorption was measured for 13 samples. All the samples were measured at subcritical $\mathrm{CO}_{2}$ pressure conditions, that is, at $3 \mathrm{MPa}$ and at a temperature of $21{ }^{\circ} \mathrm{C}$. The measurements of mass changes in the measuring and reference cells were a basis for the calculations of mass and volume of the adsorbed $\mathrm{CO}_{2}$.

The measuring cell was each time filled with sample, and the material was then compressed uniaxially with a hydraulic press to $9 \mathrm{MPa}$. This pressure was chosen to simulate lithostatic pressure conditions as approximately occurring within the Velenje lignite seam at a depth of $350 \mathrm{~m}$. In this case, the averaged specific gravity $\left(\sim 2.6 \mathrm{t} / \mathrm{m}^{3}\right)$ of overburden sediments (sands, sand- and siltstones, claystones, marls) was taken into consideration. After the compression, measuring cell with the sample was inserted into a measuring device for the gravimetric measuring of $\mathrm{CO}_{2}$ adsorption. Before the measuring of $\mathrm{CO}_{2}$ adsorption, the system was vacuumed so that there was no gas in the cells and tubes at all. The mass of the gas under pressure in both cells was determined by finding the total mass of the cells.

Calculated volumes of adsorbed $\mathrm{CO}_{2}$ per tonne of material $-c_{\text {ads }}\left(\mathrm{m}^{3} / \mathrm{t}\right)$ for different coal samples are listed in Table 2. Furthermore, lithotype and ash content on a dry basis $\left(A^{d b}\right)$ in wt $\%$ are also added.

\begin{tabular}{|c|c|c|c|c|}
\hline Sample & $\begin{array}{c}c_{\text {ads }} \mathrm{CO}_{2} \\
{\left[\mathrm{~m}^{3} / \mathrm{t}\right]}\end{array}$ & $\begin{array}{l}\text { Err. } \\
{[\%]} \\
\%\end{array}$ & $\begin{array}{l}\text { nalysed) } \\
\text { Lithotype }\end{array}$ & $\begin{array}{c}A^{d b} \\
{[\mathrm{wt} \%]}\end{array}$ \\
\hline $1 \mathrm{~V}$ & 32.37 & 2.01 & xylite & 2.69 \\
\hline $2 \mathrm{~V}$ & 34.54 & 1.13 & detro-xylite & 4.93 \\
\hline $3 \mathrm{~V}$ & 23.37 & 1.29 & xylo-detrite & 9.91 \\
\hline $4 \mathrm{~V}$ & 29.56 & 1.52 & xylo-detrite & 9.81 \\
\hline $5 \mathrm{~V}$ & 28.11 & 1.44 & detrite & 9.63 \\
\hline $6 \mathrm{~V}$ & 26.92 & 1.88 & detrite & 14.73 \\
\hline $7 \mathrm{~V}$ & 21.57 & 1.10 & detrite & 9.83 \\
\hline $8 \mathrm{~V}$ & 38.80 & 2.33 & xylite & 23.30 \\
\hline $9 \mathrm{H}$ & 31.36 & 1.37 & durain & 58.93 \\
\hline $10 \mathrm{R}$ & 35.62 & 1.19 & vitrain & n.a. \\
\hline $11 \mathrm{R}$ & 40.37 & 0.92 & vitrain & 8.47 \\
\hline $12 \mathrm{R}$ & 42.26 & 1.72 & vitrain & n.a \\
\hline $13 \mathrm{~S}$ & 38.06 & 1.67 & durain & 4.97 \\
\hline
\end{tabular}

The obtained results show that significantly different quantities of $\mathrm{CO}_{2}$ can be absorbed by different coals and their lithotype varieties (Tab. 2). The lowest value of the adsorbed $\mathrm{CO}_{2}$ volume at $3 \mathrm{MPa}$ is calculated to be $21.57 \mathrm{~m}^{3} / \mathrm{t}$ (sample $7 \mathrm{~V}$ - ortho-lignite from Velenje), while the highest value is $42.26 \mathrm{~m}^{3} / \mathrm{t}$ (sample $12 \mathrm{R}-$ bituminous coal from Raša). Considerable variations within the ortho-lignite samples exist as well. We can see that the difference between the lowest $\mathrm{CO}_{2}$ adsorption in ortho-lignite $\left(21.57 \mathrm{~m}^{3} / \mathrm{t}-\right.$ sample $\left.7 \mathrm{~V}\right)$ and the highest 
$\mathrm{CO}_{2}$ adsorption in it $\left(38.80 \mathrm{~m}^{3} / \mathrm{t}-\right.$ sample $\left.8 \mathrm{~V}\right)$ is relatively high $\left(17.23 \mathrm{~m}^{3} / \mathrm{t}\right)$. This was expected because of lithotype heterogeneity of ortho-lignites studied. Among all the investigated samples, detrital ortho-lignites (samples $3 \mathrm{~V}-7 \mathrm{~V}$ ) have the lowest $\mathrm{CO}_{2}$ adsorption capacities - from 21.57 to $29.56 \mathrm{~m}^{3} / \mathrm{t}$. Xylite-rich lithotypes (samples $1 \mathrm{~V}$ and $2 \mathrm{~V}$ ) show higher values of adsorption - between 32.5 and $34.5 \mathrm{~m}^{3} / \mathrm{t}$. Xylite sample designated as $8 \mathrm{~V}$ has even higher sorption capacity $\left(38.80 \mathrm{~m}^{3} / \mathrm{t}\right)$ than other ortho-lignite lithotypes. It has similar gas sorption properties as coals of higher ranks - various lithotypes of meta-lignites and bituminous coals (Fig. 5).

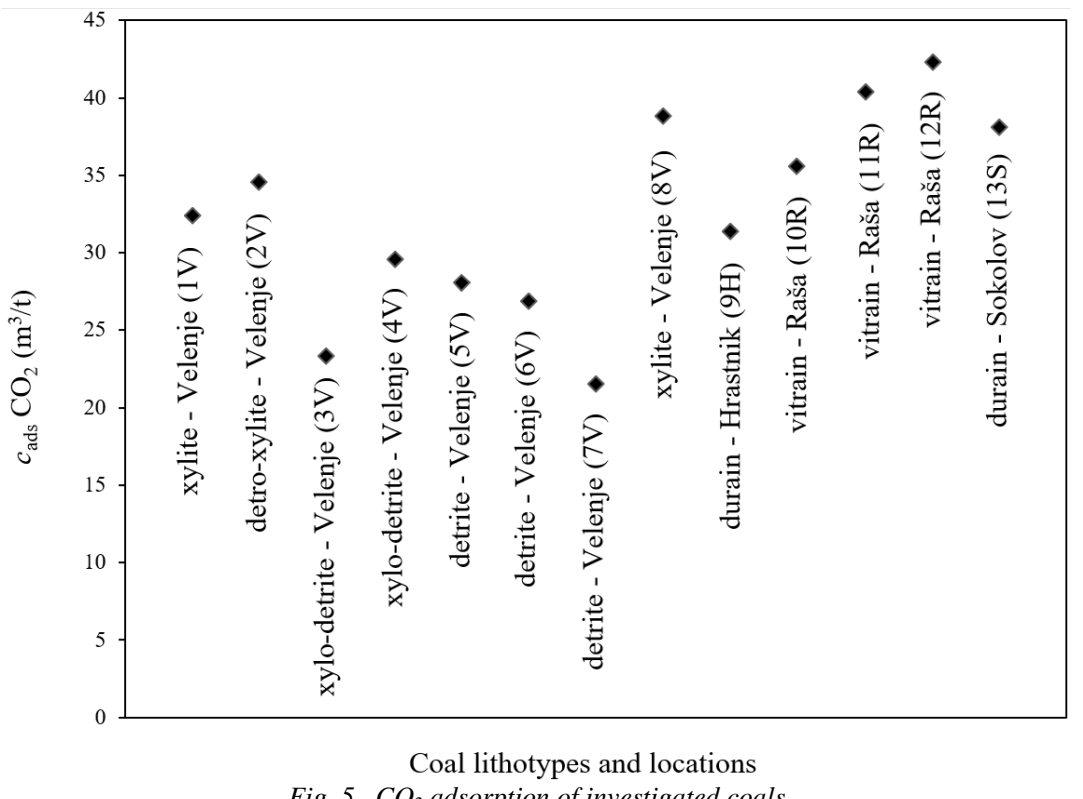

Below the micropetrographic composition and gelification index $(G I)$ are added to the $\mathrm{CO}_{2}$ adsorption capacity (Tab. 3). The gelification index $(G I)$ is the ratio of gelified macerals $(U+D s)$ versus nongelified macerals $(T x+A t t)$ (Diessel, 1992).

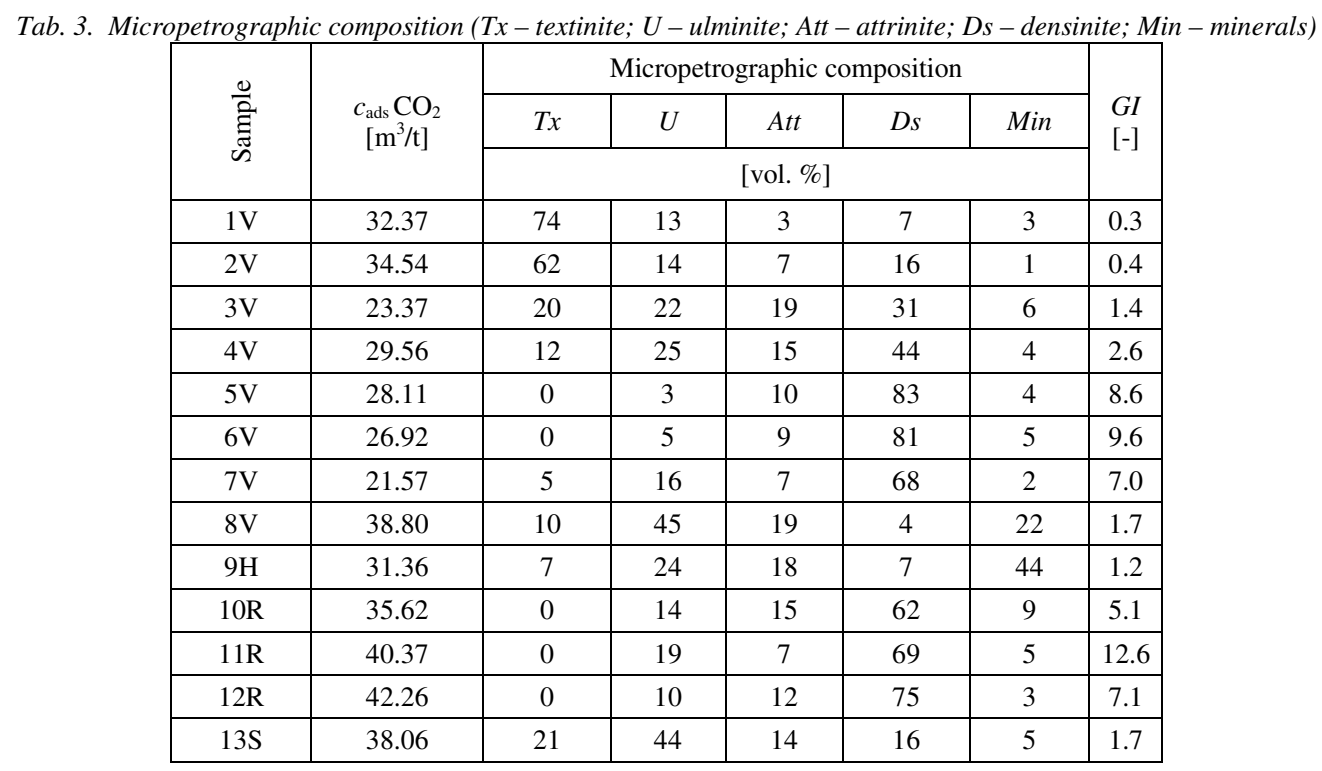

It can be concluded, taking into account the data from Table 1 and Table 3 , that the prevailing xylite $(X)$ composition of samples $1 \mathrm{~V}$ and $2 \mathrm{~V}$ well correspond to the textinite $(T x)$ composition and that the prevailing detrite $(x D+D)$ composition of samples $3 \mathrm{~V}-7 \mathrm{~V}$ well corresponds to the attrinite $(A t t)$ plus densinite $(D s)$ composition. It was expected that the $\mathrm{CO}_{2}$ adsorption capacity of ortho-lignites would rise with the increasing gelification and the content of fine detrite $(D)$, but this was not confirmed clearly in our study. Only a slight increase of the $\mathrm{CO}_{2}$ adsorption capacity versus the content of fine detrite $(D)$ can be noticed, especially if excluding sample 7V with $D=83 \%$ (Fig. 6). However, the gelification index (GI) positively correlates with the fine detrite $(D)$ content, $R^{2}=0.9456$ (Fig. 7). 


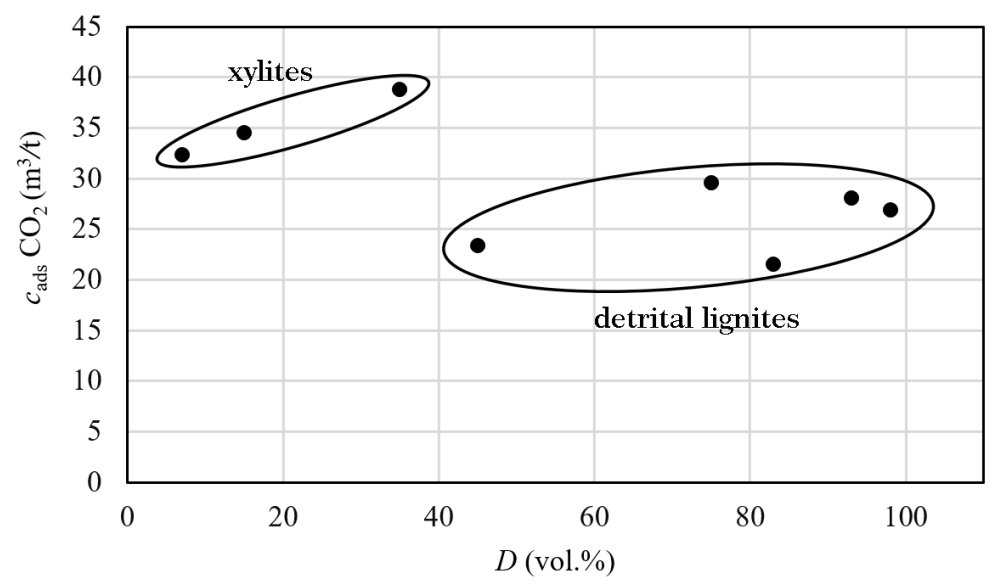

Fig. 6. $\mathrm{CO}_{2}$ adsorption of ortho-lignites in relation to the share of detrite (D)

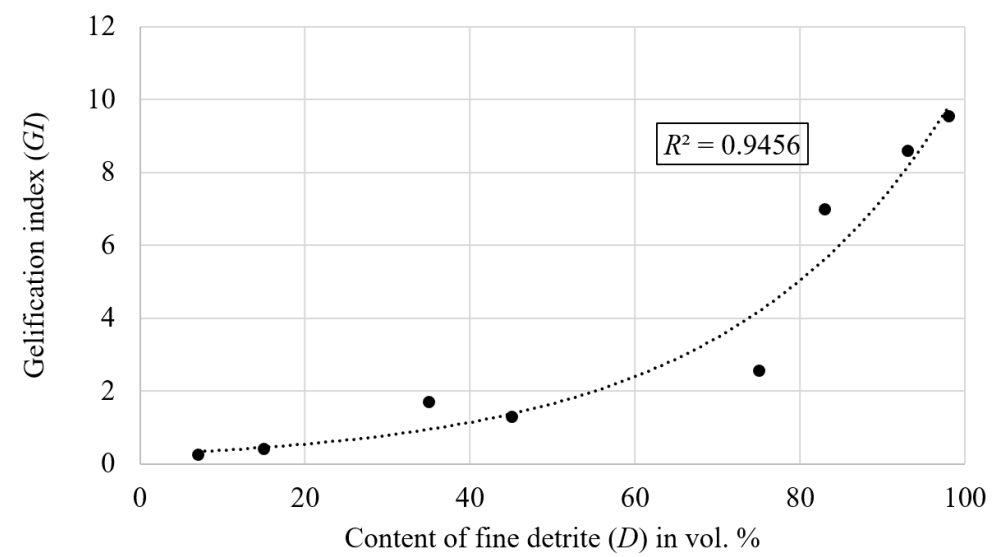

Fig. 7. Correlation between the content of fine detrite $(D)$ and gelification index (GI) of ortho-lignites

High $\mathrm{CO}_{2}$ adsorption of the xylite samples $1 \mathrm{~V}$ and $2 \mathrm{~V}$ is surprising (Tab. 2), but may be explained with the fact that both samples are very low-ash ones yielding below $5 \mathrm{wt} \%$ of ash. Also, under the microscope, we found that textinite has empty cell lumena of 5-30 $\mu \mathrm{m}$ in size - darker cells in Figure 8. Only some cells are merged and replaced by pyrite. Open-cell lumena represent great "empty" volume, although their total specific area (specific surfaces) is relatively small. The scanning electron microscopic (SEM) image shows cellular structure and pyrite in detail. On the other hand, an energy dispersive spectrum (EDS) indicates Fe and $\mathrm{S}$ peaks that are characteristic for the pyrite (Fig. 8).

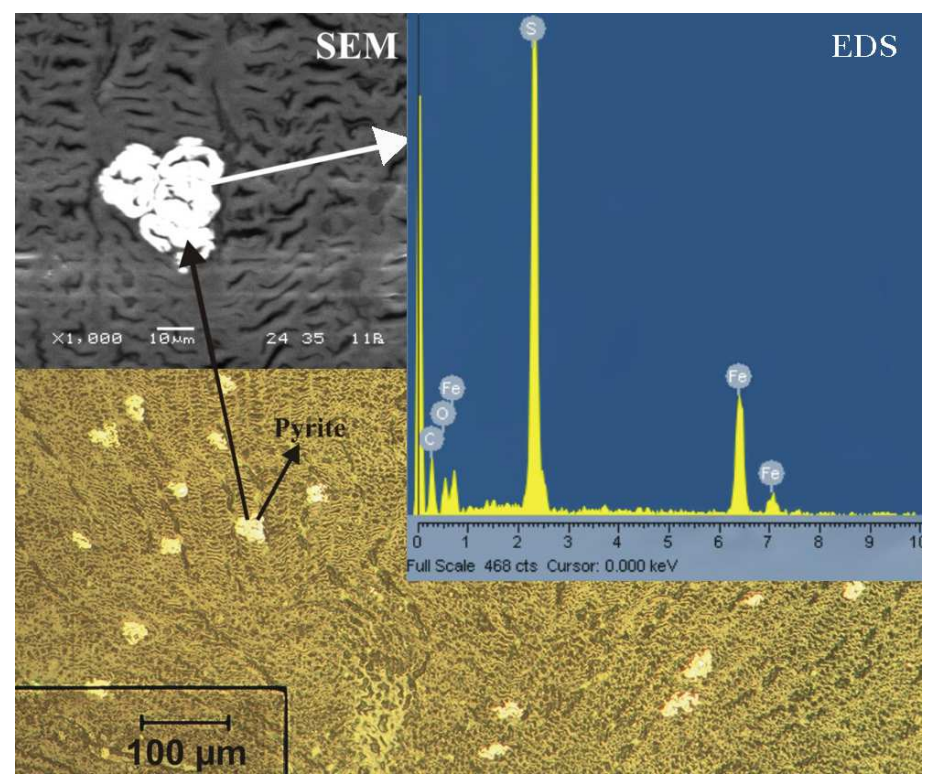

Fig. 8. Photomicrographs of textinite, typical maceral of xylite lithotype 
Lignites with the prevailing detrite component (samples $3 \mathrm{~V}$ to $7 \mathrm{~V}$ ) yielded ashes of 10 to $15 \mathrm{wt} \%$ (Tab. 2). Vitrains (samples 10R to 12R) are well known to be "clean" coals with low-ash content - below 10 wt\%. Only two samples have higher ash content - medium-ash xylite sample $8 \mathrm{~V}$ with more than $23 \mathrm{wt} \%$ of ash and durain from Hrastnik (sample 9H) with almost $60 \mathrm{wt} \%$ of ash (Tab. 2). Sample 9H can be classified as carbominerite (Taylor et al., 1998). No clear correlation between the ash yield and $\mathrm{CO}_{2}$ adsorption capacity was found.

The ortho-lignite sample defined macroscopically as xylite (sample $8 \mathrm{~V}$ ) looks microscopically as ulminite bands in alternation with attrinite (Fig. 9). Coals with high mineral content as sample $8 \mathrm{~V}$ can be slightly oxidised and their ulminite and densinite ingredients became more porous.

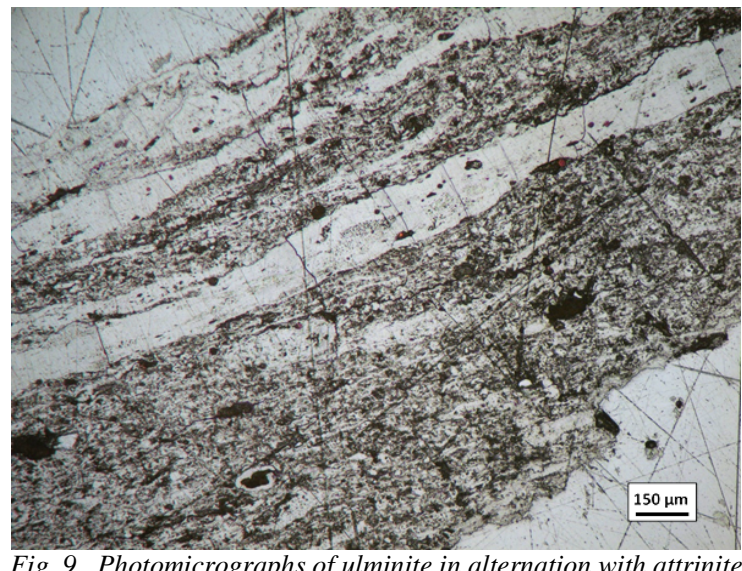

It is known from a number of studies (e.g., Faiz et al., 2007; Flores, 2014; Garnier, 2011; Gaucher et al., 2011) that high volatile bituminous coals as our samples from Raša, which did not yet achieve a peak of bituminisation, are often more prone to $\mathrm{CO}_{2}$ adsorption than lower rank coals. This phenomenon depends on the microporosity of coal and/or its microfracturing system. Simply put, highly microporous geological materials, including coals, are characterised by great specific areas (specific surfaces) of pores on which $\mathrm{CO}_{2}$ "likes" to be "tightly" and "strongly" adsorbed. For example, Zapušek and Hočevar (1998) stated, that the specific surfaces of xylitic to fine detrital lithotypes of the Velenje lignite range from 35 to almost $185 \mathrm{~m}^{2} / \mathrm{g}$ of the sample tested.

On the basis of a set of ortho-lignite samples from the Velenje deposit and the comparison of meta-lignites and bituminous coals, it can be concluded that the lowest $\mathrm{CO}_{2}$ adsorption capacities have ortho-lignites and the highest ones bituminous coals (Tab. 4, Fig. 10).

Tab. 4. An average possible volume of $\mathrm{CO}_{2}$ adsorption into different coal rank and the number of samples measured $(n)$
\begin{tabular}{|c|c|c|}
\hline Coal rank & $\begin{array}{c}c_{\mathrm{ads}} \mathrm{CO}_{2} \\
{\left[\mathrm{~m}^{3} / \mathrm{t}\right]}\end{array}$ & $\begin{array}{c}n \\
{[-]}\end{array}$ \\
\hline ortho-lignite & 29.41 & 8 \\
\hline meta-lignite & 34.71 & 2 \\
\hline bituminous coal & 39.42 & 3 \\
\hline
\end{tabular}

Ortho-lignites are petrographically more heterogeneous than meta-lignites and bituminous coals. This is most probably one of the reasons why $\mathrm{CO}_{2}$ adsorption capacity in ortho-lignite is also more variable than in higher rank coals (Fig. 10). However, xylites are "end-members" in the lithotype composition of many lignites; hence, they are not representative quantitatively for the bulk litho-typology. Thus, more representative are ortholignites of intermediate lithotype composition. As determined in this study, such ortho-lignites are composed of more than $45 \mathrm{vol} . \%$ of fine detrite. Their $\mathrm{CO}_{2}$ adsorption capacities are between 22 and $30 \mathrm{~m}^{3} / \mathrm{t}$, on average 26 $\mathrm{m}^{3} / \mathrm{t}$ of lignite. The real difference of $\mathrm{CO}_{2}$ adsorption between ortho-lignites and higher rank coals is therefore even higher.

Coals of higher rank than ortho-lignite exhibit higher possible gas adsorption - from 31 to $42 \mathrm{~m}^{3} / \mathrm{t}$ (Fig. 10). Between different coal samples (ortho-lignite, meta-lignite and bituminous coal), the most appropriate type of coal for $\mathrm{CO}_{2}$ adsorption is the bituminous coal. Considering the bituminous coals, their $\mathrm{CO}_{2}$ adsorption capacity is well comparable with the $\mathrm{CO}_{2}$ adsorption capacities that Saghafi et al. (2007) reported for sub-bituminous and bituminous coals from the Sydney Basin. Their measured adsorption capacities were in the range of 40 to 80 $\mathrm{m}^{3} / \mathrm{t}$. The mentioned researchers concluded that such coals are potentially suitable for the $\mathrm{CO}_{2}$ sequestration (Saghafi et al., 2007). 


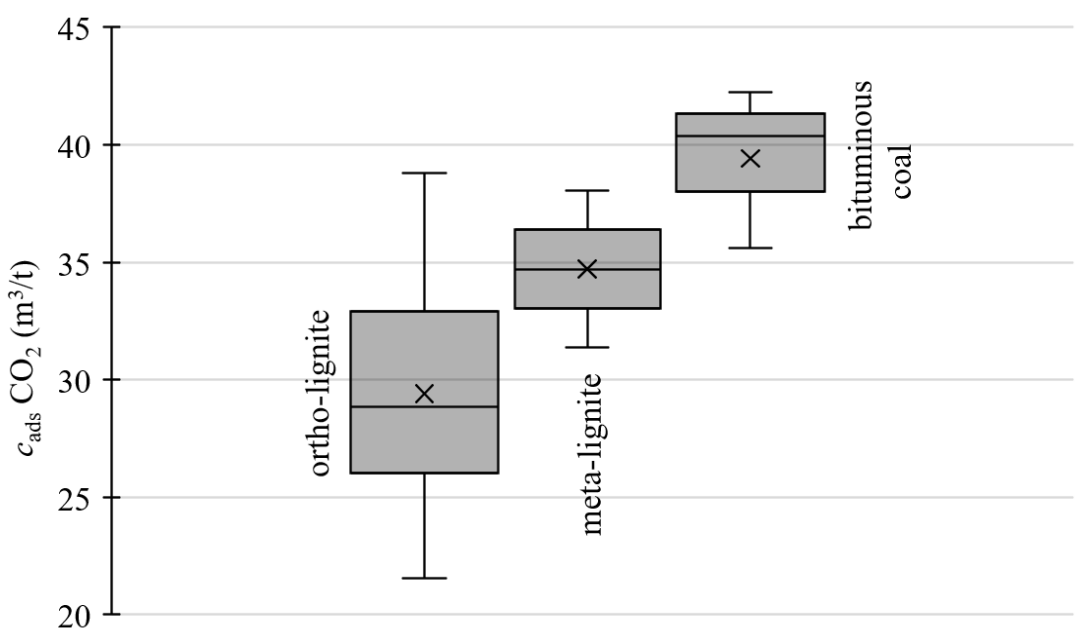

Fig. 10. Volumes of $\mathrm{CO}_{2}$ adsorption per tonne into different rank coals

\section{Conclusion}

Measurements of the $\mathrm{CO}_{2}$ adsorption by the gravimetric method have been done on 13 coal samples collected from different locations, lithotypes (having various compositions) and being of different coalification ranks - from ortho-lignites to bituminous coals. Of all the samples, 8 were from the Velenje lignite seam (Pliocene, Velenje Basin, Slovenia), 5 samples, as comparable coals, were from the Sokolov Basin (meta-lignite, Miocene, Czech Republic), Hrastnik (meta-lignite, Oligocene, Sava folds, Slovenia), and Raša (bituminous coal, Lower Eocene, Istria, Croatia). The measurements were done on dry, crushed and milled (particle size below 200 $\mu \mathrm{m})$ samples at the conditions of sub-critical $\mathrm{CO}_{2}$ pressure at $3 \mathrm{MPa}$ and at the temperature of $21{ }^{\circ} \mathrm{C}$.

The results obtained show that different ortho-lignite lithotypes can adsorb at such conditions between ca. 22 and $39 \mathrm{~m}^{3} \mathrm{CO}_{2}$ per tonne. The highest adsorption capacities that are in the range of 32.5 and $34.5 \mathrm{~m}^{3} / \mathrm{t}$ were found for two xylite-rich ortho-lignites with 85 and 93 vol.\% of the xylite component, and for one xylite sample with a high content of gelified macerals $(U+D s)$ with the adsorption capacity of almost $39 \mathrm{~m}^{3} / \mathrm{t}$. More detrital ortho-lignites, in our set of samples composed of less than 25 vol.\% of xylite to almost entirely fine detrital lignite with more than 90 vol.\% of the fine detrite component, adsorbed considerably less $\mathrm{CO}_{2}-$ between 22 and $30 \mathrm{~m}^{3} / \mathrm{t}$. It was found that only slightly increases the adsorption capacity along with fine detrital lignite and the gelification index. In the Velenje ortho-lignite seam as a whole, xylite is quantitatively subordinated in relation to lignite composed of detrite, xylo-detrite, and detro-xylite. Therefore, for these ortho-lignites the adsorption capacities between 22 and $30 \mathrm{~m}^{3} / \mathrm{t}$ seem the most realistic.

The unexpectedly high adsorption capacity of xylite (prevailingly textinite under the microscope) can be attributed to high lumena cell porosity, being non-gelified and not filled with a mineral matter or resinite. The lumena pores in "clean" (very low-ash) xylites as a sum have large volumes, but small surface areas. From this point of view, we presume that a considerable part of the injected $\mathrm{CO}_{2}$ was not only adsorbed on the surfaces of the pores but also filled the cells as a free gas.

Finally, microscopic maceral analysis of the ortho-lignites showed good correlation with their lithotypes. The gelification index increased with the increase of the fine detrital content in the tested coal samples. As expected, the higher $\mathrm{CO}_{2}$ adsorption capacities than in ortho-lignites were measured for some higher rank coals, that is, ca. $31-38 \mathrm{~m}^{3} / \mathrm{t}$ for meta-lignites and $36-42 \mathrm{~m}^{3} / \mathrm{t}$ for bituminous coals.

\section{References}

Angus, S., Armstrong, B., De Reuck, K.M. (1976). Chemical Data Series: International Thermodynamic Tables of the Fluid State 3 - Carbon Dioxide. Pergamon Press, Oxford, 385 pp.

Brezigar, A. (1987). Coal seam of the Velenje coal mine (in Slovene). Geologija 28/29, pp. 319-336.

Brezigar, A., Kosi, G., Vrhovšek, D., Velkovrh, F. (1987). Paleontological investigations of the Plio-Quaternary beds of the Velenje depression (in Slovene). Geologija 28/29, pp. 93-119.

Bruch, A.A. (1998). Palynologische Untersuchungen im Oligozän Sloweniens: Paläo-Umwelt und Paläoklima im Ostalpenraum. PhD dissertation - Tübinger Mikropaläontologische Mittaillungen 18, 193 pp.

De Silva, P.N.K. and Ranjith, P.G. (2014). Understanding the significance of in situ coal properties for $\mathrm{CO}_{2}$ sequestration: An experimental and numerical study. Int. J. Energ. Res. 38, pp. 60-69.

Diessel, C.F.K. (1992). Coal-Bearing Depositional Systems. Springer-Verlag, 721 pp. 
ECE-UN (1998). ECE-UN, Economic Commission for Europe, Committee on Sustainable Energy. International Classification of in-Seam Coals, 1998/19 document. United Nations, Geneva, 14 pp.

Faiz, M., Saghafi, A., Sherwood, N., Wang, I. (2007). The influence of petrological properties and burial history on coal methane reservoir characterisation, Sydney Basin, Australia. Int. J. Coal Geol. 1-3, pp. 193-208.

Fitzgerald, J.E., Pan, Z., Sudibandriyo, M., Robinson Jr., R.L., Gasem, K.A.M., Reeves, S. (2005). Adsorption of Methane, Nitrogen, Carbon Dioxide and their Mixtures On Wet Tiffany Coal. Fuel 84, pp. 2351-2363.

Flores, R.M. (2014). Coal and Coalbed Gas - Fueling the Future. Elsevier, 720 pp.

Flores, R.M., Rice, C.A., Stricker, G.D., Warden, A., Ellis, M.S. (2008). Methanogenic pathways of coal-bed gas in the Powder River Basin, United States: The geologic factor. Int. J. Coal Geol. 76, pp. 52-75.

Gan, H., Nandi, S.P., Walker, P.L. (1972). Nature of the porosity in American coals. Fuel 51, pp. 272-277.

Garnier, Ch., Finqueneisel, G., Zimny, T., Pokryszka, Z., Lafortune, S., Défossez, P.D.C., Gaucher, E.C. (2011). Selection of coals of different maturities for $\mathrm{CO}_{2}$ Storage by modelling of $\mathrm{CH}_{4}$ and $\mathrm{CO}_{2}$ adsorption isotherms. Int. J. Coal Geology 87, pp. 80-86.

Gaucher, E.C., Défossez, P.D.C., Bizi, M., Bonijoly, D., Disnar, J.-R., Laggoun-Défarge, F., Garnier, Ch., Finqueneisel, G., Zimny, Grgic, D., Pokryszka, Z., Lafortune, S., Vidal Gilbert, S. (2011). Coal laboratory characterisation for $\mathrm{CO}_{2}$ geological storage. Energy Procedia 4, pp. 3147-3154.

Hall, F.E., Chunhe, Z., Gasem, K.A.M., Robinson Jr., R.L., Yee, D. (1994). Adsorption of Pure Methane, Nitrogen and Carbon Dioxide and Their Binary Mixtures on Wet Fruitland Coal, in: SPE 29194, Eastern Regional Conference and Exhibition, pp. 329-344.

Hamrla, M. (1959). On the conditions of origin of the coal beds in the karst region (in Slovene). Geologija 5, pp. $180-264$.

Hartai, É. (2014). Possible options for the geological storage of carbon dioxide in Hungary. Acta Montanistica Slovaca 19 , pp. 118-125.

Humayun, R. and Tomasko, D.L. (2000). High-resolution Adsorption Isotherms of Supercritical Carbon Dioxide on Activated Carbon. Aiche J. 46, pp. 2065-2075.

ICCP, International Committee for Coal Petrology. (1993). International Handbook of Coal Petrography (3rd Supplement to 2nd ed.). University of Newcastle upon Tyne, England, 145 pp.

ISO 7404-3, 2009. Methods for the Petrographic Analysis of Coals - Part 3: Method of Determining Maceral Group Composition. International Organization for Standardization, Switzerland, 7 pp.

Kanduč, T., Pezdič, J., Lojen, S., Zavšek, S. (2003). Study of the gas composition ahead of the working face in a lignite seam from the Velenje basin. Mat. Geoenv. 50, pp. 503-511.

Kanduč, T. and Pezdič, J. (2005). Origin and distribution of coalbed gases from the Velenje basin, Slovenia. Geochem. J. 39, pp. 397-409.

Kurniawan, Y., Bhatia, S.K., Rudolph, V. (2006). Simulation of binary mixture adsorption of methane and $\mathrm{CO}_{2}$ at subcritical conditions in carbons. AIChE J. 52, pp. 957-967.

Lazar, J., Kanduč, T., Jamnikar, S., Grassa, F., Zavšek, S. (2014). Distribution, composition and origin of coalbed gases in excavation fields from the Preloge and Pesje mining areas, Velenje Basin, Slovenia. Int. J. Coal Geol. 131, pp. 363-377.

Likar, J., Runovc, F., Debelak, B., Malavašič, H. (2008). Behaviour of $\mathrm{CO}_{2}$ Saturated Lignite in Different States of Stress, in Pezdič et al. (eds.), International Workshop Velenje '08. Mine Gases $\mathrm{CO}_{2}, \mathrm{CH}_{4}$, Mine Safety, Prevention, Managing and Utilisation, Velenje, pp. 51-64.

Leung, D.Y.C., Caramanna, G., Maroto-Valer, M.M. (2014). An overview of current status of carbon dioxide capture and storage technologies. Renew. Sustain. Energ. Rev. 39, pp. 426-443.

Markič, M., Zavšek, S., Pezdič, J., Skaberne, D., Kočevar, M. (2001). Macropetrographic Characterisation of the Velenje Lignite (Slovenia). Acta Univ. Carol. Geol. 45, pp. 81-97.

Markič, M. and Sachsenhofer, R.F. (2010). The Velenje Lignite - Its Petrology and Genesis. Geological Survey of Slovenia, Ljubljana, 218 pp.

Medunić, G., Grigore, M., Dai, S., Berti, D., Hochella, M., Mastalerz, M., Valentim, B., Guedes, A., Hower. J.C. (2020). Characterisation of superhigh-organic-sulfur Raša coal, Istria, Croatia, and its environmental implication. Int. J. Coal Geol. 217, 103344.

Nagy, S. (2006). Use of carbon dioxide in underground natural gas storage processes. Acta Montanistica Slovaca 11, pp. 116-119.

Nemitallah, M.A., Abdelhafez, A.A., Ali, A., Mansir, I., Habib, M.A. (2019). Frontiers in Combustion Techniques and Burner Designs for Emissions Control and $\mathrm{CO}_{2}$ Capture: A Review. Int. J. of Energ. Res. 43, pp. 7790-7822.

Pini, R., Ottinger, S., Burlini, L., Storti, G., Mazzotti, M. (2010). Sorption of carbon dioxide, methane and nitrogen in dry coals at high pressure and moderate temperature. Int. J. Greenh. Gas Con. 4, pp. 90-101.

Rojík, P., Fejfar, O., Dašková, Z., Kvaček, J., Pešek, J., Sýkorová, Teodoridis, V. (2014). Sokolov Basin (In: Pešek, J. et al. (eds.): Tertiary basins and lignite deposits of the Czech Republic, pp. 90-142. 
Saghafi, A., Faiz, M., Roberts, D. (2007). $\mathrm{CO}_{2}$ Storage and Gas Diffusivity Properties of Coals from Sydney Basin, Australia. Int. J. Coal Geol. 70, pp. 240-254.

Senel, I.G., Gürüz, A.G., Yücel, H. (2001). Characterisation of pore structure of Turkish coals. Energ. Fuel 15, pp. 331-338.

Si, G., Durucan, S., Jamnikar, J., Lazar, J., Abraham, K., Korre, A., Shi, Y.Q., Zavšek, S., Mutke, G., Lurka, A. (2015). Seismic monitoring and analysis of excessive gas emissions in heterogeneous coal seams. Int. J. Coal Geol. 149, pp. 41-54.

Span, R. and Wagner, W. (1996). A New Equation of State for Carbon Dioxide Covering the Fluid Region from the Triple-Point Temperature to $1100 \mathrm{~K}$ at Pressures Up to $800 \mathrm{MPa}$. J. Phys. Chem. Ref. Data. 25, pp. 1509-1596.

Stach, E., Mackowsky, M.-Th., Teichmüller, M., Taylor, G.H., Chandra, D., Teichmüller, R. (1982). Stach's Textbook of Coal petrology (Third Edition). Gebrüder Borntraeger, Berlin, 535 pp.

Sudibandriyo, M., Mohammad, S.A., Robinson, R.L., Gasem, K.A.M. (2010). Ono-Kondo Lattice Model for High-Pressure Adsorption: Pure Gases. Fluid Phase Equilibr. 229, pp. 238-251.

Sýkorová, I., Pickel, W., Christanis, K., Wolf, M., Taylor, G.H., Flores, D. (2005). Classification of huminite ICCP System 1994. Int. J. Coal Geol. 62, pp. 85-106.

Tajnik, T., Kajfež-Bogataj, L., Jurač, E., Ribarič-Lasnik, C., Likar, J., Debelak, B. (2013). Investigation of Adsorption Properties of Geological Materials for $\mathrm{CO}_{2}$ Storage. Int. J. Energ. Res. 37, pp. 952-958.

Taylor, G.H., Teichmüller, M., Davis, A., Diessel, C.F.K., Littke, R., Robert, P. (1998). Organic Petrology. Gebrüder Borntraeger, Berlin, 704 pp.

Vrabec, M. (1999). Style of postsedimentary deformation in the Plio-Quaternary Velenje basin, Slovenia. Neues Jahrb. Geol. Paläontol. 1999/8, pp. 449-463.

Walker Jr., P.L. and Mahajan, O.P. (1978). Methane Diffusion in Coals and Chars, in: Karr, C. (ed.), Analytical Methods for Coal and Coal Products. vol.1. Academic Press, pp. 163-188.

Zapušek, A. and Hočevar, S. (1998). Adsorption and Desorption Properties of Lignite, in: Meunier, F. (ed.), Fundamentals of Adsorption, 6. Proceedings of the 6th International Conference of fundamentals of adsorption, Presqu'ile de Giens, pp. 653-658.

Žula, J., Pezdič, J., Zavšek, S., Burič, E. (2011). Adsorption Capacity of the Velenje Lignite: Methodology and Equipment. Mat. Geoenv. 58, pp. 193-216. 